\title{
A Study On The Socio Economic Condition Of Women Labourers Under MNREGA - A Case Study of Mysore District
}

\author{
Dr.R.H.Pavithra \\ Assistant Professor, Department of Economics, Karnataka State Open University, Muktha Gangotri, Mysore -06
}

\begin{abstract}
The MGNREGA ranks among the most powerful initiatives ever undertaken for transformation of rural livelihoods in India. The unprecedented commitment of financial resources is matched only by its imaginative architecture that promises a radically fresh programme of rural development. However, for MGNREGA to realise its potential, it must focus on raising the productivity of agriculture in India's most backward regions. This can then lead further to the creation of allied livelihoods on the foundation of water security. This is also the only way we can envision a decline in the size of the work guarantee over time, as public investment under MGNREGA leads to higher rural incomes, that in turn spurs private investment and greater incomes and employment.
\end{abstract}

\section{INTRODUCTION}

The impact of the Mahatma Gandhi National Rural Employment Guarantee Schemes (MNREGS) on rural poverty depends on a number of factors such as the outreach of the programme, participation of the poor (days of work) in the MNREGS as supplementary employment, wage earnings as well as the effect of MNREGA on the rise in market wages in agriculture and non agricultural employment. For instance the capacity of small and marginal farmer households in rain fed areas to absorb the burden of wage rise needs to be reckoned since their proportion in these areas is higher than in others. The effect of MNREGS would be positive for these farm households if the community and individual works undertaken under the scheme help in productivity enhancement of agriculture. Field evidence needs to be systematically analyzed before drawing conclusions of the programme impact. If we accept the official poverty line of Rs 816 per capita per month for rural areas for 2011-12, a typical five member household would have to earn at least Rs 48,960 per annum to be considered as non-poor. If the household participates in MNREGS for 100 days, it would earn Rs 11,354 (at the average wage paid), which works out to about 23.2 per cent of the poverty line. It is obvious that if the household is moderate poor (i.e., with an income between 75 to 100 per cent of the poverty line) it can move out of the poverty for that year if it is provided 100 days (transient poverty) of work. However, if the year happens to be an agriculturally bad year then the chances of such households crossing the poverty line even after fully participating in the scheme would diminish. The chances of getting more than 100 days of employment in the scheme and in particular, in periods of crisis depend upon the commitment of the state to poverty reduction.

\section{Objectives}

- $\quad$ To study the impact of MNREG programme on social conditions of rural households in study area

- $\quad$ To explain the impact of MNREG programme on income and savings pattern among rural households in study area.

\section{HYPOTHESES :}

$\mathrm{H} 0$ : There is no association between socio economic condition of women labourers and MNREGA.

$\mathrm{H} 1$ : There is an association between socio economic condition of women labourers and MNREGA.

\section{METHODOLOGY}

The present study is on empirical investigation based on sample interview of women dairy in Mysore district. Mysore district consists of 7 taluks viz, Mysore, K.R.Nagar, Hunsur, Periyapatna, H.D.Kote, Nanajanagud, T.Narasipur. 10 women respondents from each (05) taluk has taken, totally 50 women respondents are considered. The present study is based on both primary and secondary data and a systematic random sampling method has been adopted for survey. The primary data has collected from 5 taluks by excluding the advanced taluk i,e Mysore taluk and less advanced taluk i,e H.D.Kote taluk. The survey has been conducted by taking 50 beneficiaries of MGNREG Programme of case study on 


\section{International Advanced Research Journal in Science, Engineering and Technology}

Vol. 8, Issue 8, August 2021

DOI: $10.17148 /$ IARJSET.2021.8834

random basis. Simple table percentage method used to analyse the results and the results have been depicted by simple bar graph and pie chart.

\section{REVIEW OF LITERATURE}

Dreeze and Lal (2007) based on his studies on NREGS in Rajasthan concluded that this state stands first in terms of employment generation per rural household under this scheme. They stated that in 2006-07 the average rural households in six "NREGA Districts" of Rajasthan got work for 77 days under this programme earning nearly Rs.4,000 in the process. This was held by them to be an unprecedented achievement in the history of social security in India. Disadvantaged sections of the population, they further added, are the main gainers of the programme benefits. They also found that the share of women in NREGA employment to be about two thirds in Rajasthan, and that of scheduled caste and scheduled tribe households to be as high as 80 percent. In this way this Act contributes to social equality and economic redistribution. These figures, they stated, are based on official data released by the Ministry of Rural Development, but they are fully consistent with independent reports, as well as their own experience from Dungarpur district in April 2006.

Mishra, (2007) stated that funds for the national employment guarantee scheme are being misused in U.P. and that all this is happening because of nexus among village heads, government officials and politicians. He also raised the questions as to why can ${ }^{\text {ee }}$ the NREGA workers be integrated into PM"s roads project, where they can act as a force multiplier for machine-aided projects.

\section{RESULT AND DISCUSSION}

Table : 1 Age composition

\begin{tabular}{|l|l|l|}
\hline Age & Respondents & Percentage \\
\hline $18-25$ & 10 & 20 \\
\hline $25-40$ & 30 & 60 \\
\hline $40-55$ & 6 & 12 \\
\hline Above 55 & 4 & 8 \\
\hline Total & 50 & 100 \\
\hline \multicolumn{2}{|c|}{ Source : Field Survey } \\
\hline
\end{tabular}

Table 1 shows that 10 respondents belong to the age group of 18 to 25 years, 30 respondents were under the age group of 25-40 years, 6 respondents were to the age group of 40 - 55 years and only 4 belong to the age group of above 55 .

Table - 2 Educational status

\begin{tabular}{|l|l|l|}
\hline Educational Status & Respondents & Percentage \\
\hline Illiterate & 27 & 54 \\
\hline Primary & 6 & 12 \\
\hline Secondary & 13 & 26 \\
\hline PUC & 4 & 8 \\
\hline Total & 50 & 100 \\
\hline
\end{tabular}

Source : Field Survey

Table 2 explains that 27 respondents are illiterates, 6 have their primary education, 13 are secondary educated and only 4 are PUC educated.

Table -3 Ration Card

\begin{tabular}{|l|l|l|}
\hline Card type & Respondents & percentage \\
\hline APL & $\mathbf{1 0}$ & $\mathbf{2 0}$ \\
\hline BPL & $\mathbf{3 6}$ & $\mathbf{7 2}$ \\
\hline Anthyodaya & $\mathbf{4}$ & $\mathbf{8}$ \\
\hline Total & $\mathbf{5 0}$ & $\mathbf{1 0 0}$ \\
\hline
\end{tabular}

Source : Field Survey 


\section{Respondents}

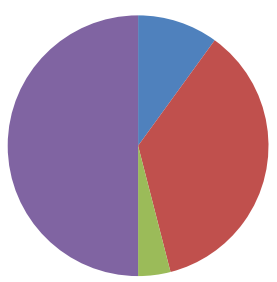

$$
\begin{aligned}
& \text { APL } \\
& \text { BPL } \\
& \text { Anthyodaya } \\
& \text { Total }
\end{aligned}
$$

Table 3 shows that 36 respondents have BPL card, 10 have APL cards and only 4 of them had Anthodaya card that means around large majority (72 percent) of them belongs to below poverty line.

Table 4 Source of Income

\begin{tabular}{|l|l|l|}
\hline & \multicolumn{2}{|c|}{ After MNREGP } \\
\hline Source & Respondents & percentage \\
\hline Agriculture & 26 & 52 \\
\hline Live stock farming & 4 & 8 \\
\hline Seasonal work & 12 & 24 \\
\hline Daily wages & 8 & 16 \\
\hline Total & 50 & 100 \\
\hline
\end{tabular}

Table 4 illustrates the sources of income where 26 respondents are working in agricultural sector, 4 in livestock farming, 12 in seasonal work and 8 as daily wage earners.

Table 5 Annual Income

\begin{tabular}{|l|l|l|}
\hline \multicolumn{1}{|c|}{ Income level } & Respondents & percentage \\
\hline Less than 10,000 & 7 & 14 \\
\hline $10,000-25000$ & 25 & 50 \\
\hline Above 25,000 & 18 & 36 \\
\hline Total & 50 & 100 \\
\hline
\end{tabular}

Source : Field Survey

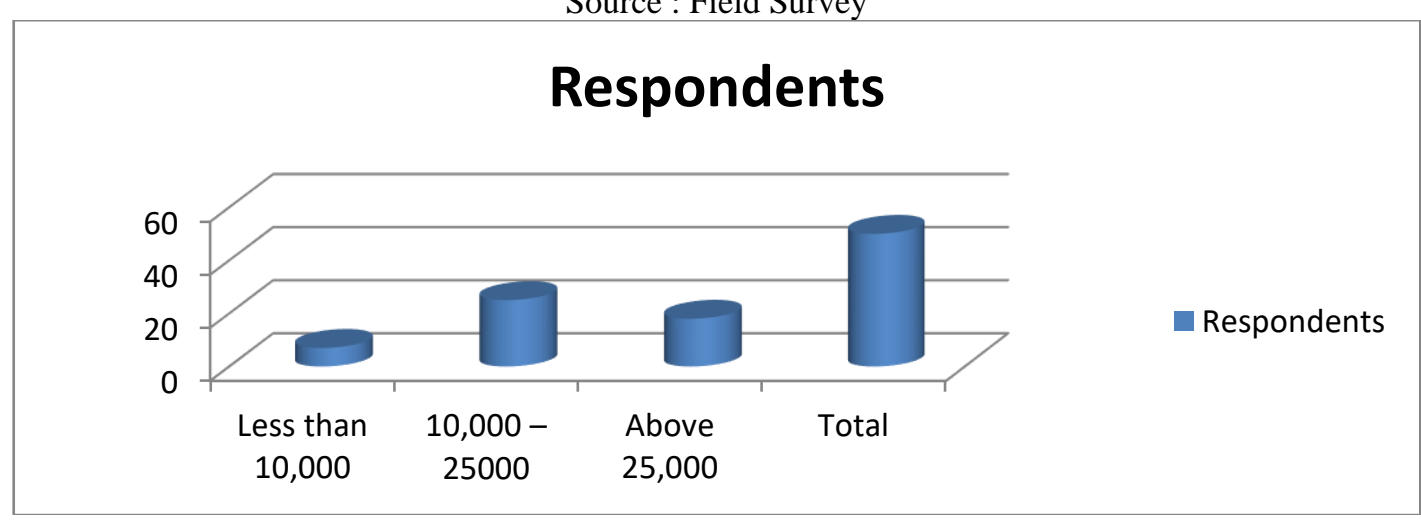

Table 5 reveals that only 7 respondents' income is less than 10,000 per annum, around 25 of them have their income range between $10,000-25,000$ and 18 respondents come under the range of above 25,000 of income per annum. 


\section{International Advanced Research Journal in Science, Engineering and Technology}

Vol. 8, Issue 8, August 2021

DOI: $10.17148 /$ IARJSET.2021.8834

Table 5 Annual Savings

\begin{tabular}{|l|l|l|}
\hline Savings pattern & Respondents & percentage \\
\hline Increased savings & 38 & 76 \\
\hline $\begin{array}{l}\text { Remains the } \\
\text { same }\end{array}$ & 4 & 8 \\
\hline No savings & 8 & 16 \\
\hline Total & 50 & 100 \\
\hline
\end{tabular}

Source : Field Survey

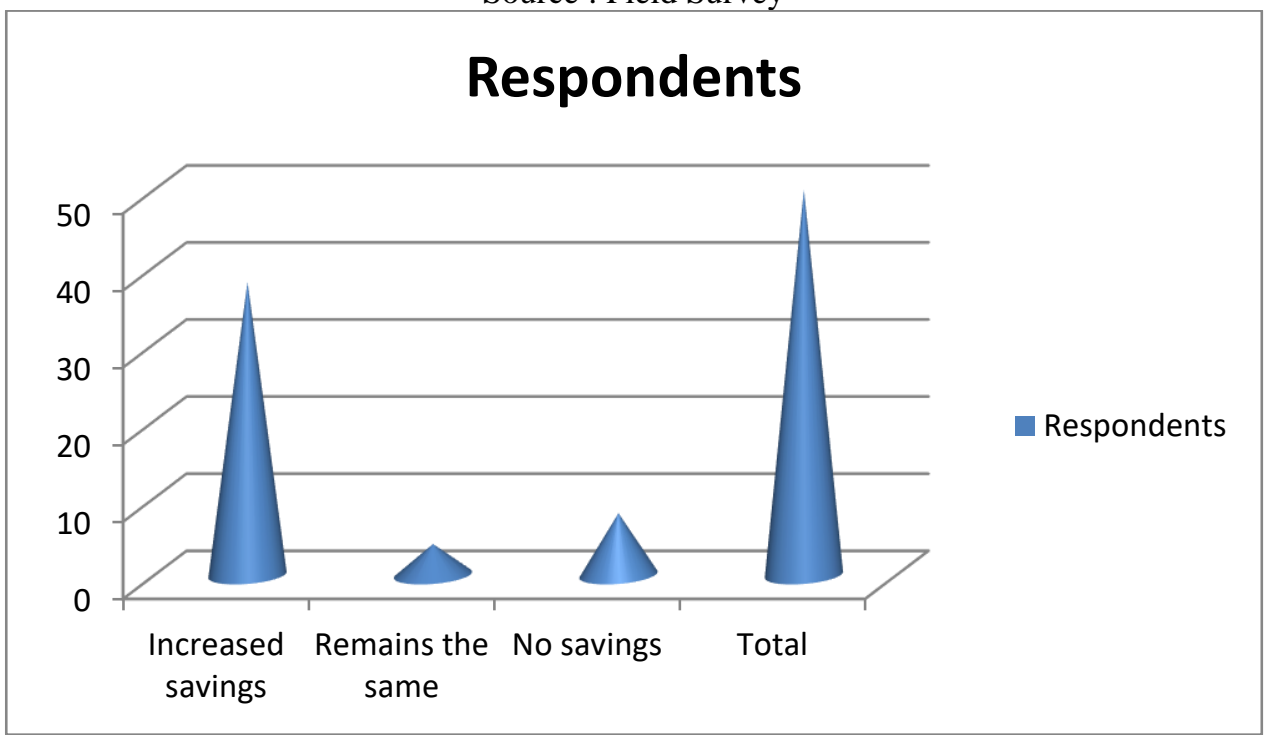

Table 5 explains that 38 respondents have opined that their savings have increased, only 4 said that their savings have remained the same, around 8 of them replied that they do not have any savings.

\section{Findings}

- $\quad$ Majority of female respondents belong to the age group of 25-40 years because that age permits them to pursue hard labour and majority of women labourers were influenced mainly due to equal payment in par with men in this scheme.

- Majority of the respondents (54\%) of them were illiterate because female literacy is very low in India, Karnataka and even in the case study area.

- Large number of respondents $(72 \%)$ of them are BPL card holders which shows that they are still below poverty line.

- It is found that after the implementation of MNREG Act the sources of income is mainly from agricultural sector followed by seasonal work.

- $\quad$ Around 50 percent of respondents have their income between 11000 to 25000 per annum which shows the improvement in the economic condition of the female labourers after the implementation of MNREG act.

- $\quad 76$ percent of respondents have opined that MNREGA have increased their savings by giving an employment opportunity.

\section{RESULTS:}

CHI SQUARE TEST

\begin{tabular}{|l|l|l|}
\hline Chi Square & Value & Level of Significance \\
\hline & 8.4098 & 0.05 \\
\hline
\end{tabular}

The Chi Square of $\mathrm{P}$ value is 8.4098. It is significant at 5 percent level. 95 percent shows that there is an association between socio economic condition of women labourers and MNREGA. Therefore, it has to reject null hypotheses and has to accept alternative hypotheses 


\section{International Advanced Research Journal in Science, Engineering and Technology}

Vol. 8, Issue 8, August 2021

DOI: $10.17148 /$ IARJSET.2021.8834

\section{Recommendations}

- $\quad$ The number of man days has to be enhanced throughout the year.

- $\quad$ Government and also some NGOs should make an attempt to create awareness about the benefits of this Act especially to the women and marginalized groups.

- $\quad$ Wage level has to be increased to improve the socio economic condition of working folk.

- $\quad$ Provident fund, ESI facalities has be given to the labourers of this scheme.

\section{CONCLUSION}

Large scale social security programmes like MGNREA are subjected to undergo several stumbling blocks. Government and NGOs must study the impact of MGNREGA in rural areas so as to ensure that this massive anti-poverty scheme is not getting diluted from its actual path and to see that the disparity in terms of socio-economic condition of women folk and marginalised groups in rural areas is reduced to considerable extend.

\section{REFERENCES}

1. All-India Report on Evaluation of NREGA A Survey of Twenty Districts, by Institute of Applied Manpower Research, (PEO), Planning Commission.

2. B.G. Harish, N. Nagaray, M.G. Chandrakanth .... (2011). Impacts and Implications of MGNREGA on labour supply and Income Generation for Agriculture in central Dry Zone of Karnataka.

3. Bhargava K. Anil (2013), The Impact of India's Rural employment Guarantee on Demand for Labour Saving Technology, University of California.

4. Disa Sjoblom and John Farrington (2008) Indian National Rural Employment Guarantee Act: Will it reduce poverty and boost economy? Oversees development institute

5. Shah Mihir, Shanker V. and Ambasta P. (2008). Two years of NREGA : The Road Ahed, Economic Political Weekly, Feb. 23.

6. The Hindu dated November 11, 2011 cover page article titled "another excuse to cut Government spending"

7. The New Indian Express dated 8th Dec, 2011- cover page titled "Pay Wages for Rural Job Scheme through Banks and POs accounts" Ramesh - page No.6

8. Thomas Bigi and Bhatia Ruby (2012), Impact of NREGA Scheme: A Study on the overall quality of life of its Beneficiaries (A Study undertaken among beneficiaries of 3 districts of Gujarat State).

9. Nikhat Tabasum; B S Hugar. "Gender Differences Pertaining To Work-Life Balance". International Research Journal on Advanced Science Hub, 2, Special Issue ICARD 2020, 2020, 187-192. doi: 10.47392/irjash.2020.117

10. Antony Carla S.; Sumathi M.. "Maximum lifespan prediction of women from Modified Weibull Distribution". International Research Journal on Advanced Science Hub, 3, 3, 2021, 56-60. doi: 10.47392/irjash.2021.097

11. Penchalaiah N.; Susmitha M.; Vinay Kumar Reddy C.; Pavan Kalyan Rao D. V.; Sreelekha D.. "An IoT Based Smart Wearable Device for Women Safety". International Research Journal on Advanced Science Hub, 3, Special Issue ICITCA-2021 5S, $2021,89-95$.

12. Thomas Solinski, NREGA and Labour migration in India : Is village life what the 'rural' poor want? 